\title{
Molecules and fossils reveal punctuated diversification in Caribbean "faviid" corals
}

\author{
Sonja A Schwartz ${ }^{*}$, Ann F Budd ${ }^{2}$ and David B Carlon ${ }^{3}$
}

\begin{abstract}
Background: Even with well-known sampling biases, the fossil record is key to understanding macro-evolutionary patterns. During the Miocene to Pleistocene in the Caribbean Sea, the fossil record of scleractinian corals shows a remarkable period of rapid diversification followed by massive extinction. Here we combine a time-calibrated molecular phylogeny based on three nuclear introns with an updated fossil stratigraphy to examine patterns of radiation and extinction in Caribbean corals within the traditional family Faviidae.

Results: Concatenated phylogenetic analysis showed most species of Caribbean faviids were monophyletic, with the exception of two Manicina species. The time-calibrated tree revealed the stem group originated around the closure of the Tethys Sea (17.0 Ma), while the genus Manicina diversified during the Late Miocene $(8.20 \mathrm{Ma})$, when increased sedimentation and productivity may have favored free-living, heterotrophic species. Reef and shallow water specialists, represented by Diploria and Favia, originate at the beginning of the Pliocene ( $5-6 \mathrm{Ma})$ as the Isthmus of Panama shoaled and regional productivity declined.

Conclusions: Later origination of the stem group than predicted from the fossil record corroborates the hypothesis of morphological convergence in Diploria and Favia genera. Our data support the rapid evolution of morphological and life-history traits among faviid corals that can be linked to Mio-Pliocene environmental changes.
\end{abstract}

Keywords: Scleractinia, Speciation, Adaptive radiation, Miocene, Pliocene, Coral reef

\section{Background}

Explaining rapid diversification and speciation remains a central challenge to evolutionary biology [1,2]. Much work has focused on either understanding the ecology and phylogenetic history of species-rich systems that have recently diversified along ecological axes (e.g. adaptive radiations) [3], or looking for patterns of species change in the fossil record [4-8]. Taking the molecular phylogenetic/ecological approach alone, however, excludes information about extinct lineages that may substantially bias our ability to identify cases of rapid diversification [9]. Conversely, relying on the fossil record alone limits our ability to detect evolutionary relationships between fossil taxa and some shifts in ecological function that may not be apparent from fossil character states. Ultimately, a more complete understanding of the processes that drive rapid diversification will require

\footnotetext{
* Correspondence: sonja.schwartz@berkeley.edu

'Department of Environmental Science, Policy \& Management, University of California, Berkeley, CA 94720, USA

Full list of author information is available at the end of the article
}

historical information from both molecular and fossil data. By examining systems that show recent speciation within monophyletic groups, ecological differentiation, and a strong fossil record, we can begin to link past to present processes in the understanding of the evolution of diversity.

The marine Caribbean fauna provides rare examples of diversification of monophyletic lineages within the context of well-understood changes in biogeography, oceanography, and climate. The isolation of Caribbean populations from their Indo-Pacific counterparts started 15-17 Ma when the closure of the Tethys Sea cut off connections between the Mediterranean and IndoPacific [10]. Isolation was complete $\sim 3.45-4.25 \mathrm{Ma}$ when the rise of the Isthmus of Panama severed all Caribbean connections to the Indo-Pacific [11]. The period leading up to closure of the isthmus during the late Miocene to late Pliocene was characterized by changing global oceanographic circulation patterns, leading to drastic environmental, ecological, and taxonomic shifts within the Caribbean basin. Not only did the

\section{Biomed Central}


cessation of gene flow between the Pacific and Atlantic Oceans lead to widespread vicariant speciation across the newly formed isthmus [12-14], but on the Caribbean side, the accompanying geological and oceanographic changes caused an overall decrease in depth, primary productivity and turbidity and an increase in salinity, temperature, and local environmental heterogeneity $[11,15]$. Fossil records of many marine taxa during this period show elevated levels of taxonomic turnover $[11,16-21]$, suggesting that climatic and geological variables drove elevated rates of cladogenesis and extinction.

This taxonomic turnover is particularly striking in corals of the family Faviidae, where an examination of the stratigraphic ranges shows that all extant species originated nearly simultaneously during the Mio-Pliocene [22]. Moreover, for faviids, this recent radiation has resulted in impressive diversification of ecological and life-history traits [23,24]. Modern species of Manicina are representative of a free-living lifestyle adapted to sediment-rich seagrass habitats that expanded during the Miocene then contracted during the Plio-Pleistocene [15]. In contrast, species of the brain coral genus Diploria tend to be reef-builders, dominating shallow water reef platforms in Pleistocene and modern times [25-28]. These two "sediment" and "reef" clades appear to share a common ancestor and ecological diversification seems to have occurred over a short period of geological time, suggesting it is tied to the contemporaneous increase in environmental heterogeneity [29]. Yet this punctuated diversification event is inferred from a fossil record, which may be incomplete or contain uncertainties in dating and taxonomic relationships that may influence our interpretation of past patterns.

Molecular data combined with well sampled fossil records provide opportunities to test existing evolutionary hypotheses and extend our understanding of both the tempo and mode of evolutionary diversification. In the Scleractinia, deep divergences between coral orders, suborders and families are increasingly well understood [30-33]. Yet a recent series of phylogenies exploring relationships at the familial level and below have demonstrated pervasive polyphyly and paraphyly at the generic level [34-39]. In addition, these studies have shown that between ocean basins, species group geographically rather than taxonomically $[35,38,39]$. In particular, Atlantic lineages of Faviidae and Mussidae appear to be more closely related to other Atlantic lineages than to congeners or even confamilials in other ocean basins. This geographic split supports the evidence from the fossil record of a radiation of the Caribbean coral fauna before complete isolation from the Pacific. However, the failure to resolve species relationships within the traditional coral family Faviidae, and a long history of taxonomic difficulties in identifying and classifying corals $[32,36,40]$ demands an independent assessment of trends apparent in the fossil record.

To explore the tempo and mode of this evolutionary diversification, we unite a new multi-locus phylogeny of the Caribbean Faviidae with new stratigraphic compilations from the fossil record. Our well-sampled phylogeny allows Bayesian approaches to place these relationships into a temporal context by dating divergence times based on molecular data and fossil calibrations. We compare our time-calibrated phylogeny to temporal patterns of origination and extinction revealed by the Neogene fossil record, and find remarkable congruence between data sets. The timing of events revealed by this analysis strongly implicates paleoenvironmental changes as drivers of diversification in scleractinian corals.

\section{Results}

Phylogenetic analysis of Caribbean "Faviidae"

We sequenced three single copy nuclear loci for six ingroup and one outgroup Caribbean faviid species. A total of 48 unique alleles were identified for CaM (alignment length $=507 \mathrm{bp}$ ), 38 alleles were identified for MaSC-1 (alignment length $=490 \mathrm{bp}$ ), and 55 alleles were identified for Pax $-C$ (alignment length $=418$ bp) (Additional file 1). Maximum likelihood and Bayesian analysis of gene trees showed little support for structure above the species level with no conflict between trees at highly supported nodes (Additional file 2). The taxa Manicina areolata and M. mayori shared some alleles at all loci, and unique alleles isolated from Diploria clivosa and D. strigosa did not always form monophyletic groups. A total of 94 individuals with unique genotypes were successfully sequenced at all three loci and used for a concatenated phylogenetic analysis. See Additional file 3 for genotype data of all individuals in study.

Bayesian and maximum likelihood trees had identical topologies at all major nodes with support values (Bayesian/ML bootstrap) indicated in Figure 1. The ingroup node was well supported $(100 / 100)$ as well as species nodes for $C$. natans (100/100), D. clivosa (100/100), D. labyrinthiformis (100/98), D. strigosa (100/98) and F. fragum (100/100). Manicina mayori and Manicina areolata failed to form monophyletic groups, though support was high at the genus node for Manicina (100/ 94). The genus Diploria failed to form a monophyletic group. Diploria clivosa formed a clade with Manicina spp. and D. strigosa formed a clade with Favia fragum. Support for these nodes, however, was low (72/68 and $76 / 60$ respectively).

\section{Timing of divergence}

BEAST analysis of the data produced a tree topologically consistent with those of the MrBayes and RaxML analyses. Visual inspection of plots in Tracer v1.5 [41] 


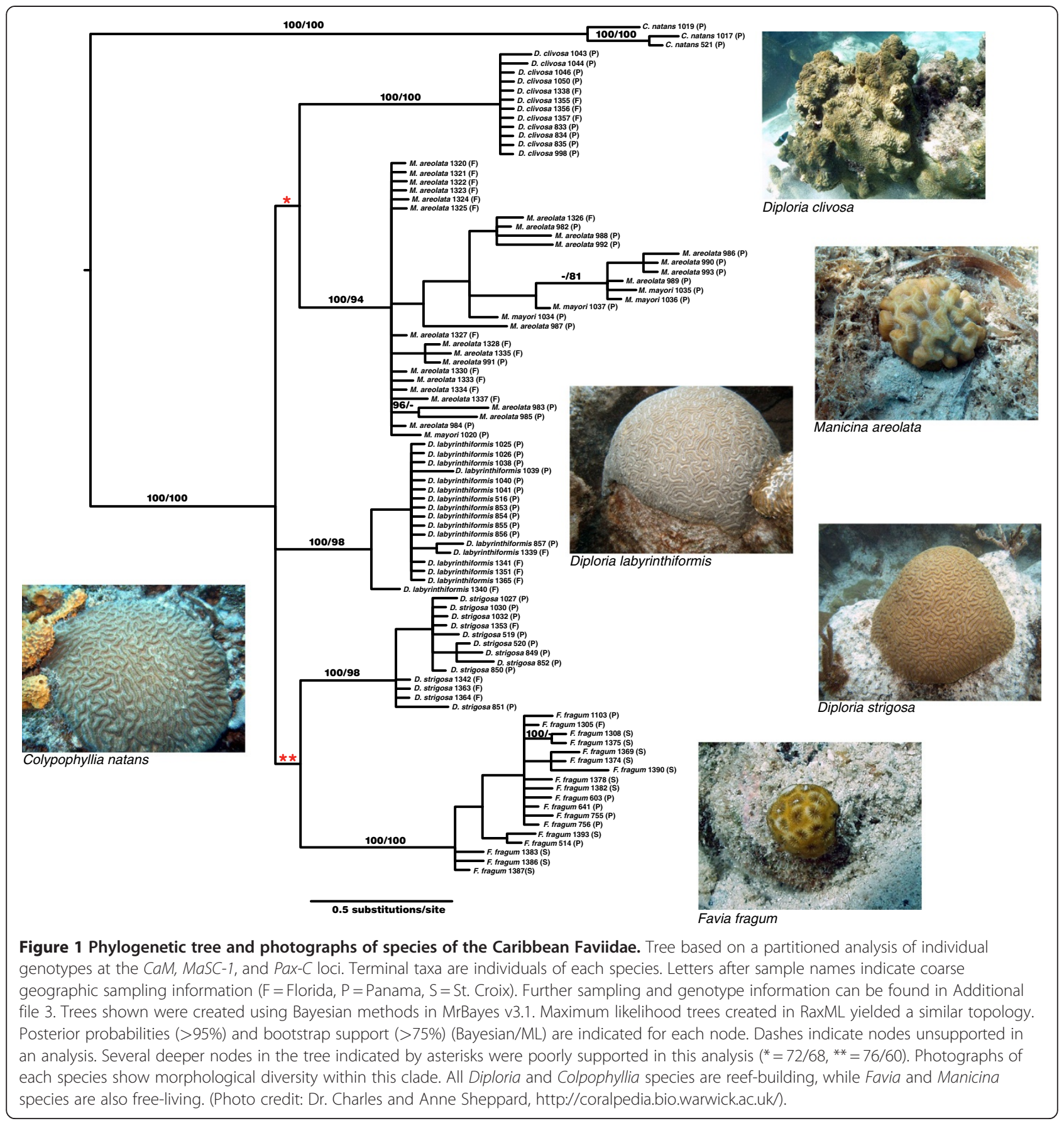

showed rapid convergence of the analysis and narrowing of priors with all parameters having an effective sample size (ESS) of $>1900$. The mean rate of substitution was $6.77 \times 10^{-4}$ per site $(95 \%$ Highest Posterior Density (HPD) interval: $4.49 \times 10^{-4}-9.06 \times 10^{-4}$ ) with a coefficient of variation of 1.17 (95\% HPD interval: 0.66- 1.72) indicating significant heterogeneity in substitution rates across the tree.

Mean ages of species, ingroup, and root nodes with 95\% HPD intervals are shown in Figure 2A and listed in
Table 1. The posterior mean of the time of the most recent common ancestor (TMRCA) of the Manicina group, which was calibrated from species fossil data, shifted several MY from the prior distribution, indicating that the sequence data is influencing divergence dates. For D. clivosa, D. strigosa, and F. fragum, mean estimated ages fell close to the earliest possible dates of their appearance in the fossil record. For the D. labyrinthiformis and Manicina nodes, fossil dates were closer to the youngest part of the 95\% HPD interval. Mean 
A.

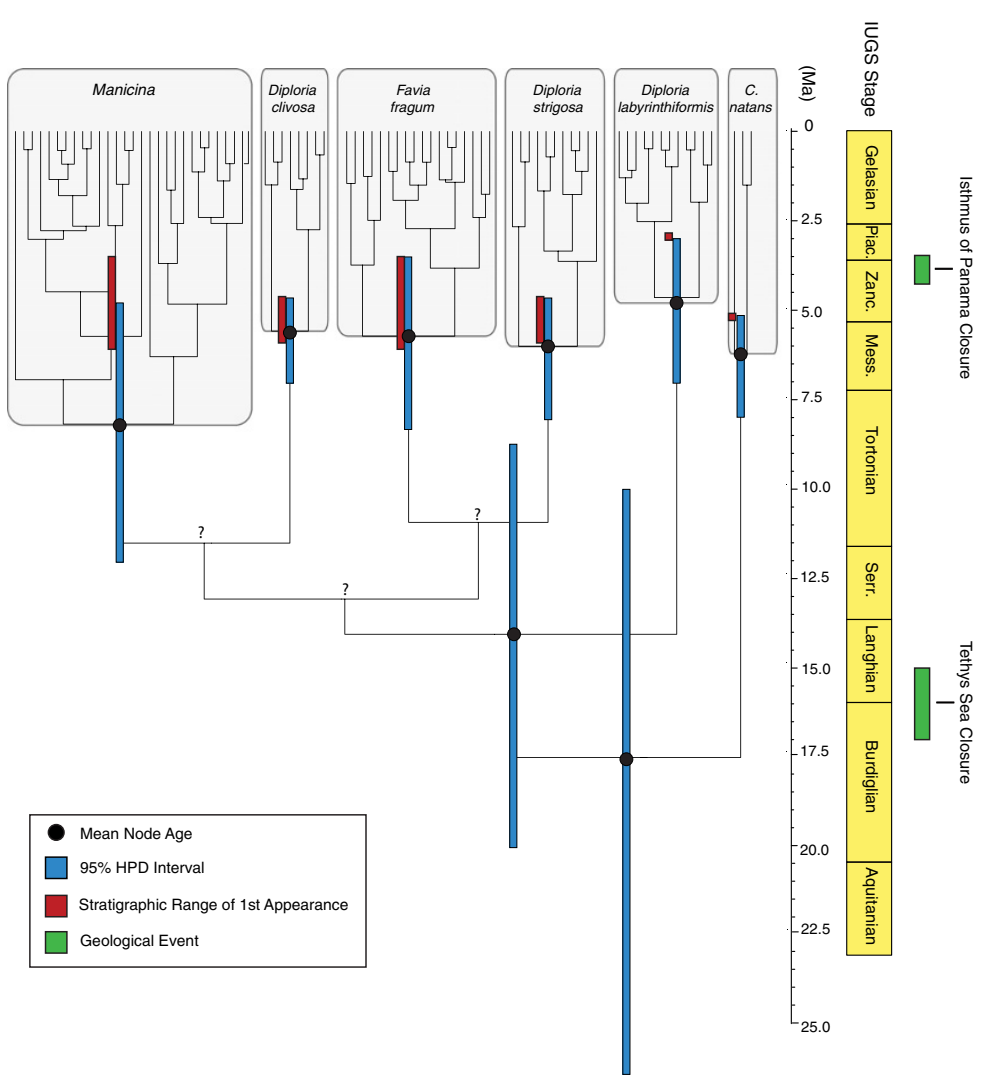

B.
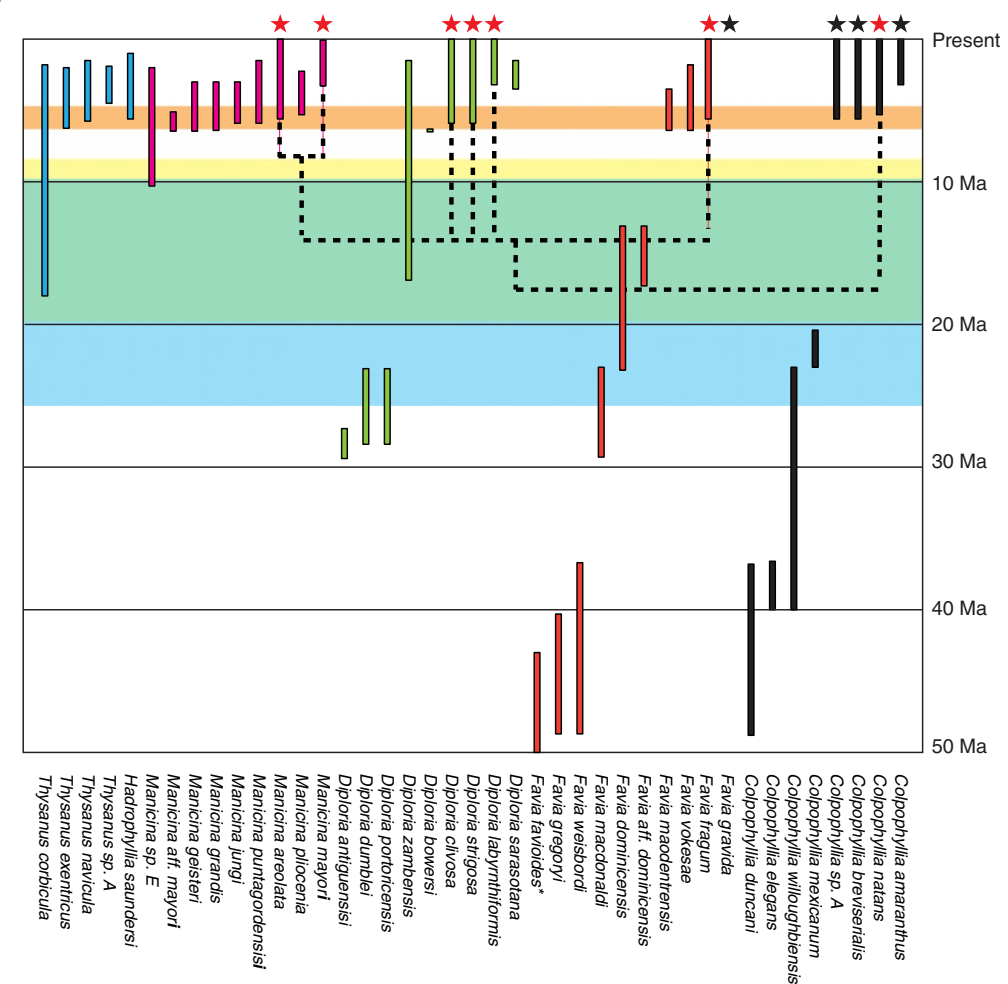

Figure 2 (See legend on next page.) 
(See figure on previous page.)

Figure 2 Caribbean Faviidae chronogram and stratigraphic data. A) Divergence dates of terminal (species) and internal nodes of a phylogeny of the Caribbean Faviidae. Original chronogram and tree generated in BEAST. Grey boxes indicate species or genera as labeled. Black circles and blue bars correspond to mean node age (Ma) and 95\% HPD intervals produced by BEAST analysis. Red bars indicate the stratigraphic age range of the first appearance of that taxon in the fossil record. Green bars next to the time axis are used to indicate major geological events in the isolation of the Caribbean Sea including the closure of the Central American Isthmus at 4.25-3.5 Ma and the closure of the Tethys Sea at 17-15 Ma. Nodes marked with a '?' are poorly supported in this analysis. Detailed information about dates and node calibration can be found in Tables 1 and 2. B) Phylogeny on stratigraphy of living and extinct species. Stratigraphic range bars are color-coded by genera, listed on the $x$ axis. Green + blue shading are 95\% highest posterior density (HPD) intervals for the ingroup node, and green + yellow shading are 95\% HPD intervals for the root node as seen on the chronogram. Orange shading indicates the range of origination dates in the fossil record for all living taxa. Species within genera are ranked by earliest origination date, left to right. The genera Thysanus and Hadrophyllia are free living, as are all the extinct species of Manicina. See Additional file 5 for stratigraphic references. (*Favia favioides range extends to $65.5 \mathrm{Ma}-$ not shown).

origination time of D. labyrinthiformis is pushed back approximately 1.6 MY earlier than previously seen in the fossil record, putting it closer to the origination times of the other species. All mean species origination dates occur shortly prior to the final closure of the Central American Isthmus at $4.25-3.45 \mathrm{Ma}$ [11], but we note that the youngest part of 95\% HPD for $F$. fragum and D. labyrinthiformis overlap with this estimated age of final closure. The timing of the Manicina node is considerably earlier than the appearance of the Manicina areolata in the fossil record, indicating that this genus diverged earlier than the first appearance of $M$. areolata. Deeper nodes in the tree had significantly larger HPD confidence intervals, due to the lack of fossil calibrations for earlier taxa. The estimate of origination time for the ingroup was $14.10 \mathrm{Ma}$ (95\% HPD interval: 8.77-20.09), while origination of the entire Caribbean Faviidae group is indicated by the root node at $17.56 \mathrm{Ma}$ (95\% HPD interval: 10.04-26.44). These dates coincide with the timing of the closure of the Tethys Sea in the eastern Mediterranean [10].

Overlay of the molecular phylogeny onto the fossil stratigraphy reveals three striking patterns (Figure 2B). First, older and extinct Diploria and Favia cannot be reconciled with this molecular tree, suggesting these genera are not monophyletic. Second, the origination and diversification of a clade of sediment dwelling corals

Table 1 Divergence dates estimated from BEAST

\begin{tabular}{lccc}
\hline Taxa & \multicolumn{3}{l}{ Date of Origination - Ma } \\
\cline { 2 - 4 } & Mean & Median & $\begin{array}{l}\text { 95\% Highest Posterior } \\
\text { Density (HPD) interval }\end{array}$ \\
\hline C. natans & 6.25 & 6.01 & $5.16-8.02$ \\
F. fragum & 5.74 & 5.53 & $3.52-8.36$ \\
D. clivosa & 5.60 & 5.41 & $4.67-7.06$ \\
D. labyrinthiformis & 4.66 & 4.37 & $3.01-7.06$ \\
D. strigosa & 6.03 & 5.76 & $4.67-8.08$ \\
Manicina & 8.21 & 7.97 & $4.81-12.08$ \\
Ingroup & 14.10 & 13.70 & $8.77-20.09$ \\
Root & 17.56 & 16.86 & $10.04-26.44$ \\
\hline
\end{tabular}

(particularly Thysanus and Manicina) is confirmed by both the fossil record and molecular phylogeny. Lastly, the appearance of new reef dwelling species of Favia and Diploria is simultaneous in the fossil record around 5 Ma.

\section{Discussion}

\section{Phylogenetic relationships within modern Caribbean corals}

Thorough sampling of individuals within species in our combined phylogenetic analysis confirms that most modern Caribbean species form well-supported monophyletic lineages (Figure 1). This allows us to reject the idea that widespread hybridization on ecological time scales [42] is important to the evolution of Caribbean faviids, though limited introgression not detected by this data set might have played a creative role in adaptive processes [43]. The exception lies within the two modern species of Manicina, M. areolata and M. mayori, where extensive allele sharing between species might indicate sub-species status. While $M$. areolata is a seagrass specialist, and drifts remarkable distances on the sediment surface as a free-living adult [44], M. mayori is a rare reef species that remains permanently attached as an adult. In Panama, these two morphologically distinct species co-occur within sites yet segregate ecologically by depth-related habitats. An approach that combines ecological/reproductive comparisons, morphometric data, and further genetic analyses such as the coalescent-based model of isolation and migration [45] could resolve this issue.

Above the species level, we could not further resolve the branching order of species within the larger clade. Previous single locus phylogenies using mitochondrial and nuclear genes that have included this group have shown a similar lack of resolution within the Caribbean faviids[35,36]. Another study by Nunes et al. [39] shows some supported structure within this group. However, as this paper was looking mainly at broader scale phylogeographic relationships, sampling was done on only few individuals per species within the Caribbean faviids and 
using only a single mitochondrial marker and a single nuclear marker. For examining relationships below the familial level, the low rates of mtDNA evolution in corals might limit the ability to detect more complex topologies amongst these species. With the increased sampling sizes of multiple loci with higher levels of variation (Additional file 2), we found little evidence for monophyly within genera, and branch lengths tended to be long (Figure 1). Therefore, our inability to resolve relationships among species is consistent with rapid diversification and short internal branch lengths deeper in the tree. With the rapidly declining cost of high throughput sequencing, a phylogenomic approach $[46,47]$ for this set of taxa is likely to improve topological resolution.

\section{Fossils and molecules reveal the tempo and mode of Caribbean coral diversification}

Molecular divergence dating indicates extant Caribbean "faviid" corals radiated rapidly during the late Miocene to early Pliocene (Figure 2). This ecological radiation coincides with a series of biological and physical changes in the structure of shallow marine habitats during the early geological development of the Isthmus of Panama. During the Late Miocene, shallow marine habitats were dominated by broader and more gently sloping sedimentary shelves [48], while productivity in the water column above was much higher compared to the modern productivity of the Caribbean Sea [49]. Klaus et al. [15] hypothesize that these extensive mesophotic sedimentary bottoms may have selected for free-living coral species with large tentacle morphologies that were efficient at heterotrophic feeding. Interestingly, our node age for the clade containing the two living Manicina species is 8.21 Ma, which coincides with the appearance of other sibling Manicina species in the fossil record that have since gone extinct [22]. Thus, it appears we are sampling the evolutionary remnants of a once more diverse and ecologically dominant clade. As the Miocene transitions into the Pliocene, the increasingly isolated Caribbean Sea becomes more oligotrophic and the once broad shelf habitats are now dominated by steeper reef platforms, ideal conditions for primarily photoautotrophic reef species. Our time-calibrated phylogeny shows repeated speciation events of Diploria and Favia species between $\sim 4-6 \mathrm{Ma}$ that are either reef specialists or are limited to very shallow $(<5 \mathrm{~m})$ seagrass habitats. Thus the fossil record and molecular data broadly agree on the timing of these ecological radiations, which are temporally correlated with changes in habitat structure and productivity.

Deeper in the tree, node ages for the stem groups of the Caribbean faviids correspond to the isolation from the Mediterranean during the closure of the Tethys
Sea (Figure 2A). While these dates support the widely accepted notion of divergence driven by increased isolation of the region, the radiation of the stem group is much later than indicated by the fossil record (Figure 2B). The origination of the Favia-DiploriaManicina (FDM) clade is in the early Miocene, but older Oligocene Diploria fossils and Eocene Favia fossils are more distantly related, suggesting that both genera are para- or polyphyletic. Ken Johnson reached a similar conclusion based on morphological differences [22], hypothesizing that early Diploria and Favia are unrelated to their modern morphological counterparts. Morphological convergence appears to be a common theme in coral evolution [35] and our analysis points out some of the difficulties in determining the systematic positions of extinct taxa. The use of more informative microstructural characters that can be quantified in both living and fossil species may be a promising approach to this problem [30].

Congruence of morphology, stratigraphy, and estimates of node ages can be used to include fossil taxa into potentially monophyletic lineages. For example, the diverse members of living and fossil taxa of the genus Manicina form a well-supported monophyletic group in Johnson's morphological phylogeny with all fossil origination dates falling within the lower confidence interval for the molecular Manicina node age (Figure 2A). Superimposing the age-calibrated molecular phylogeny onto stratigraphy significantly alters the interpretation of the speed of evolution in this group (Figure 2B), indicating rapid diversification of sediment dwelling corals in the late Miocene.

\section{Are punctuated patterns driven by adaptation?}

Our time calibrated phylogeny confirms fossil evidence that extant Caribbean coral species originated during a period of lineage diversification between 4 and $6 \mathrm{Ma}$ (Figure 2). This diversification event corresponds with ecological radiation into three main ecological niches exemplified by modern Caribbean faviids [21]: (i) small, free living morphologies adapted to sedimentary environments (ii) attached species that live in shallow rubble beds and patch reefs, and (iii) massive colonies the build forereef slopes (Figure 1). During the same period, we also see diversification of reproductive strategies [23], from tightly synchronized annual mass-spawning events and broadcasting larvae typical of Diploria [24] to multiple lunar cycles of reproduction and brooding development found in Favia and Manicina [50,51].

The changes in morphology and life history coupled with widespread environmental changes are suggestive that diversification of Atlantic "faviid" coral might be driven by the evolution of adaptive traits. Using our current phylogeny as a stepping stone, increased genomic 
and taxonomic sampling of Atlantic corals should allow us to take advantage of several promising new approaches to estimate rates of diversification and evaluate models of adaptive radiation $[52,53]$.

\section{Conclusions}

By combining data from the fossil record with molecular phylogenetic techniques for the first time, this study has given us extensive insight into the tempo of diversification in an ecologically diverse group of Caribbean corals. Two separate lines of evidence now verify the existence of a Mio-Pliocene radiation, while we have been able to additionally confirm species identity, verify origination dates, and understand taxonomic relationships in this diverse and ecologically important group. These findings give us the tools to re-interpret trends seen in the fossil record, allowing us to begin to link patterns of macroevolution to paleoenvironmental changes and gain a new comprehension into the origins and drivers of diversity in the Caribbean.

Besides clarifying evolutionary history, this study has broader contemporary implications. With global change currently causing a rapid decline in coral reef populations around the world $[54,55]$, understanding the processes that generated diversity in coral species will be key to predicting future changes and directing conservation efforts [56]. It has been suggested that species that evolved in a more heterogeneous environment and survived past climatic fluctuations will be more resistant to current global change [29]. Understanding patterns of Caribbean coral evolution during the Pleistocene may be key to understanding the potential outcomes of current environmental impacts.

\section{Methods}

\section{Taxon sampling}

We sampled six of the seven nominal species from the genera Favia, Diploria, and Manicina that form a monophyletic group within the Caribbean Faviidae [35,39]. The single missing taxon is Favia gravida, closely related to Favia fragum, but with a distinct non-Caribbean distribution in that it has been only described from Brazil and West Africa $[57,58]$. We used the genus Colpophyllia as the outgroup because it has previously been shown to be a stem taxon to the ingroup species [35,39]. Extensive sampling within each species was conducted at two reef systems in the Caribbean Sea: the Bocas del Toro, Panama, and the Florida Keys, USA with additional $F$. fragum sampled from St. Croix, USVI. The complete list of samples and collection localities is provided in Additional file 3. Skeletal vouchers are deposited in the University of Iowa Paleontology Repository (http:// geoscience.clas.uiowa.edu/paleo/index). Samples were collected, preserved, and genomic DNA extracted as described in Carlon and Lippé [59]. Skeletal vouchers were processed by bleaching in a $50 \%$ hypochlorite/water solution overnight, rinsing in DI water, and thoroughly drying. Species identification was conducted by D. Carlon in the field and confirmed by A. Budd from vouchers. Complete descriptions of these taxa, photos, and references are available from the Neogene Marine Biota of Tropical American (NMITA) database (http:// eusmilia.geology.uiowa.edu/).

\section{Laboratory protocols}

For this study we chose to focus on nuclear markers, since rates of mitochondrial DNA evolution have been shown to be very slow in corals, limiting the ability to detect more recent speciation events [60]. We amplified three single-copy nuclear regions with primers listed in Additional file 4. Pax-C and CaM primers target introns located within the Pax protein and calmodulin binding protein respectively[61,62], while $M a S C-1$ is an anonymous region originally sequenced in Montastraea annularis [63]. For PCR amplification of all three loci, we combined: $1 \mu \mathrm{l}$ of $1 \mathrm{x}$ to $100 \mathrm{x}$ diluted genomic DNA with a $24 \mu \mathrm{l} \mathrm{PCR}$ master mix consisting of: $0.3 \mu \mathrm{l}$ of each primer $(10 \mu \mathrm{M}), 1 \mu \mathrm{l}$ dNTPs (2.5 mM each), $2.5 \mu \mathrm{l} 10 \mathrm{x}$ reaction buffer, $1 \mu \mathrm{MgCl}_{2}(25 \mathrm{mM}), 1 \mu \mathrm{l} \mathrm{BSA}(10 \mathrm{mg} / \mathrm{ml})$, $0.3 \mu \mathrm{l}$ Taq polymerase (Bioline), and $17.6 \mu \mathrm{l}$ of $\mathrm{H}_{2} \mathrm{O}$. Each reaction was run at $95{ }^{\circ} \mathrm{C}$ for $10 \mathrm{~min}, 30$ cycles of $94{ }^{\circ} \mathrm{C}$ for 30s, Ta for 40 s and $72{ }^{\circ} \mathrm{C}$ for $1 \mathrm{~min}$, with a final extension of $72{ }^{\circ} \mathrm{C}$ for 10 minutes. Purified PCR products were sequenced on ABI 3731 XL 96 capillary DNA analyzers at the University of Hawaii at Manoa and chromatograms were then analyzed and edited using Sequencher 4.5 (Gene Codes). Direct reads revealed indels segregating within many of the species, and preliminary cloning verified multiple indels within all three genes. Since phasing length-variant heterozygotes (LVHs) from direct reads proved unreliable, we cloned $86 \%$ of the PCR products from individuals with LVH phenotypes. We cloned PCR products using a TOPO TA cloning kit (Invitrogen) and sequenced using standard M13 primers. Single nucleotide polymorphism heterozygotes were phased using the software PHASE v2.1.1 [64,65]. We used the non-recombination model, and phase thresholds of 0.90. To convert data between FASTA and PHASE formats, we used the webtool SeqPHASE [66]. Haplotype sequence data are available as Genbank PopSets. Accession numbers are listed by species in Additional file 1.

\section{Phylogenetic analyses \\ Gene trees}

Allele sequences were aligned automatically using MAFFT v6 $[67,68]$, and corrected by eye in MacCladev4.08 [69]. Indels were coded as missing data. Models 
for molecular evolution for Bayesian analysis for both gene trees and the partitioned tree were selected using the Akaike Information Criteria (AIC) in jModelTest v0.1.1 [70,71]. For the gene trees, the best fitting model for the CaM and Pax-C alignment was GTR + G, and for $M a S C-1$ the model was GTR. Bayesian trees for all three loci were generated in MrBayes v3.1 (5,000,000 generations, nruns $=2$, nchains $=4)[72,73]$. Trees were sampled every 100 generations and 5,000 trees were discarded as burn-in. Maximum likelihood analysis was performed using RaxML 7.2.6 [74,75] with 1000 rapid bootstraps using the default GTR $+\mathrm{G}$ model for all loci at the recommendation of the programmers.

\section{Partitioned trees}

Individuals sequenced at all three loci were used for the construction of a combined partitioned tree. For heterozygotes, SNPs were coded as ambiguous data using standard IUPAC nucleotide ambiguity codes. For the Bayesian analysis, the $\mathrm{K} 80+\mathrm{G}$ model was chosen for the CaM partition, the HKY + I + G model for theMaSC-1 partitions, and the HKY model for the Pax-C partition. Bayesian trees were generated using MrBayes v3.1 $(20,000,000$ generations, nruns $=4$, nchains $=4)$. Trees were sampled every 1000 generations and 5000 trees were discarded as burn-in. Maximum likelihood analysis was performed using RaxML v7.2.6 with 1000 rapid bootstraps on the Cipres Web Server [76]. For this analysis, the default GTR + G model was used as above.

\section{Divergence dating}

The program BEAST v1.7.1 [77] was used to estimate divergence dates at species nodes using available fossil data for calibration. Input files for the analysis were generated with Beauti v1.5.4 using a partitioned alignment file of 80 individuals. We used a Yule process speciation prior for branching rates along with an uncorrelated lognormal model for a relaxed molecular clock. Models for molecular evolution for BEAST analysis were selected using the Akaike Information Criteria (AIC) in MrModelTest v2.2 [78]. The $\mathrm{HKY}+\mathrm{G}$ model was used for the CaM and MaSC-1 partitions, and the $\mathrm{HKY}+\mathrm{I}$ model for the Pax $-\mathrm{C}$ partition. Base frequencies were estimated throughout the analysis. Based on the phylogenetic analysis, all species nodes were constrained to be monophyletic except for $M$. areolata and $M$. mayori, which were constrained at the genus node. Shape parameter priors were taken from MrModeltest v2.2 and priors for rates of evolution and Yule birth rates were chosen based on defaults narrowed from preliminary runs.

Stratigraphic ranges of extinct and living Caribbean Faviidae were compiled from the literature and unpublished sources (Additional file 5). Fossil stratigraphic ranges for extant species were used to calibrate species nodes for Diploria spp., Favia fragum and Colpophyllia
Table 2 Stratigraphic ranges, BEAST calibrations, and section references

\begin{tabular}{llll}
\hline Species & $\begin{array}{l}\text { Fossil Date of } \\
\text { 1st occurrence } \\
\text { (Ma) }\end{array}$ & $\begin{array}{l}\text { Node Calibration } \\
\text { (mean, standard } \\
\text { deviation, offset) }\end{array}$ & $\begin{array}{l}\text { Median } \mathbf{( 9 5 \%} \\
\text { interval) }\end{array}$ \\
\hline C. natans & $5.1-5.3$ & $0.5,1,5.1$ & $6.7(5.3-16.8)$ \\
F. fragum & $3.0-5.6$ & $1.1,0.8,3.0$ & $6.0(3.8-17.4)$ \\
D. clivosa & $4.6-5.9$ & $0.6,1,4.6$ & $6.4(4.9-17.5)$ \\
D. labyrinthiformis & $2.9-3.1$ & $0.7,1,2.9$ & $4.9(3.2-17.2)$ \\
D. strigosa & $4.6-5.9$ & $0.6,1,4.6$ & $6.4(4.9-17.5)$ \\
M. areolata & $3.0-5.6$ & $1.1,0.8,3.0^{*}$ & $6.0(3.8-17.4)$ \\
M. mayori & $2.9-3.1$ & $\mathrm{n} / \mathrm{a}^{*}$ & \\
\hline
\end{tabular}

Ranges in fossil dates of first occurrence reflect accuracy of section dating. References for dates can be found in Additional file 5. *Calibration for Manicina is at genus node since species not well supported in phylogeny.

natans and the genus node for Manicina (Table 2). Calibrations of nodes were done following the guidelines of Ho and Phillips [79]. For all date priors, we used a lognormal distribution with a hard minimum bound set at youngest possible date of first appearance in the fossil record. The mode of the distribution was set to be slightly older than the oldest possible date of first appearance. Finally, the $95 \%$ probability distribution was set to encompass a soft maximum bound at the time of the closure of the Tethys $(\sim 17 \mathrm{Ma})$. These distributions incorporate the best-known estimates for origination dates of these taxa, but are wide enough to allow for shifts in dates that may reflect errors due to interpretation or incompleteness of the fossil record.

BEAST was run 4 times (generations $=20,000,000$, samplefreq $=1000$ ) on the Bioportal webserver at the University of Oslo [80]. Log files were examined in Tracer v.1.5 [41] to assess convergence of each run. After a $10 \%$ burn-in was removed, logs and trees for all runs were combined in LogCombiner v1.7.1 and chronograms were generated with Tree Annotater v1.7.1.

\section{Additional files}

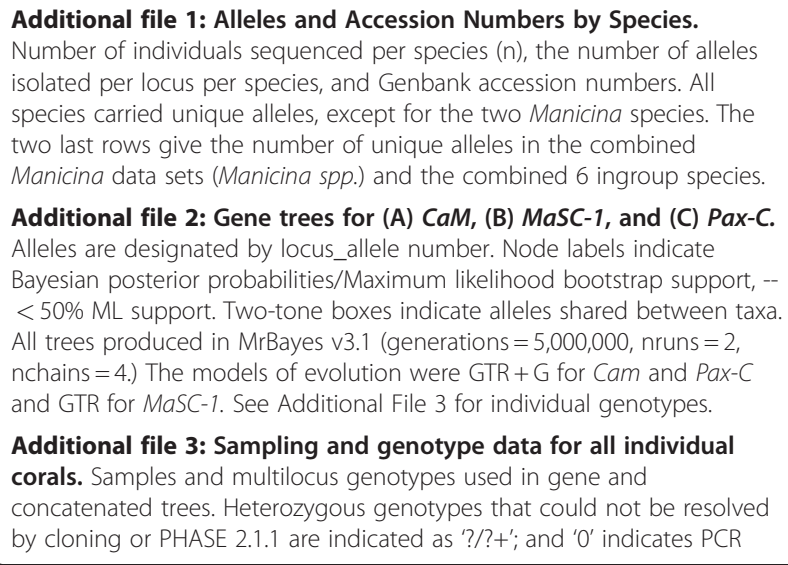


failure or poor sequence quality. The two last columns designate which samples were used in the concatenated ML/Bayes trees (Figure 1) and the BEAST analysis (Figure 2).

Additional file 4: Primers used for direct sequencing. Sequences and annealing temperatures for primers used in this study.

Additional file 5: Stratigraphic Ranges of the Fossil Caribbean

Faviidae. Compiled first and last occurrence data, references, and notes for all Caribbean fossil faviid species.

\section{Competing interests}

The authors declare they have no competing interests.

\section{Authors' contributions}

SAS designed the study, generated molecular sequence data, ran phylogenetic analyses, and drafted the manuscript. AFB confirmed morphological identification of species, compiled stratigraphic data, and helped draft the manuscript. DBC participated in the study design, collected field samples, ran phylogenetic and phasing analyses, and helped draft the manuscript. All authors read and approved the final manuscript.

\section{Acknowledgements}

We thank S. Barnes, J. Coloma, J. Fitzpatrick, and S. Walls for help collecting in the field. Brendan Holland kindly provided Diploria samples from the Flower Garden Banks. Collections from St. Croix were funded by a grant from the University Research Expeditions Program, University of California (UREP) and we thank all expedition participants for excellent field assistance. Allen Chen's lab graciously provided the original Calmodulin primers. Thanks to Joanna Bince for her assistance in sequencing and cloning introns, and George Roderick for lab space and computer time for the final portions of the analysis. All corals were collected by permits from the Republic of Panama (ANAM and CITES) and the Florida Keys National Marine Sanctuary. Our field work in Panama benefited from the extremely helpful staff of the Smithsonian Tropical Research Institutes Bocas del Toro Station. This research was supported by a grant from the National Science Foundation (DEB-05-43661) awarded to DBC.

\section{Author details}

'Department of Environmental Science, Policy \& Management, University of California, Berkeley, CA 94720, USA. ${ }^{2}$ Department of Geoscience, University of lowa, lowa City IA52242, USA. ${ }^{3}$ Department of Biology, University of Hawaii at Manoa, Honolulu, HI 96822, USA.

\section{Received: 15 December 2011 Accepted: 25 July 2012}

Published: 25 July 2012

\section{References}

1. Schluter D: The ecology of adaptive radiation. Oxford: Oxford University Press; 2000.

2. Gavrilets S: Fitness landscapes and the origin of species. Princeton, NJ: Princeton University Press; 2004

3. Givnish TJ, Systma KJ: Molecular evolution and adaptive radiation. Cambridge (United Kingdom): Cambridge University Press; 1997.

4. Budd AF, Pandolfi JM: Evolutionary Novelty Is Concentrated at the Edge of Coral Species Distributions. Science 2010, 328(5985):1558-1561.

5. Jackson JBC, Cheetham AH: Tempo and mode of speciation in the sea. Trends Ecol Evol 1999, 14(2):72-77.

6. Geary DH, Hunt G, Magyar I, Schreiber H: The paradox of gradualism: phyletic evolution in two lineages of lymnocardiid bivalves (Lake Pannon, central Europe). Paleobiology 2010, 36(4):592-614.

7. Hull PM, Norris RD: Evidence for abrupt speciation in a classic case of gradual evolution. Proc Natl Acad Sci USA 2009, 106(50):21224-21229.

8. Hunt $\mathrm{G}$ : The relative importance of directional change, random walks, and stasis in the evolution of fossil lineages. Proc Natl Acad Sci USA 2007, 104(47):18404-18408.

9. Gavrilets S, Losos JB: Adaptive Radiation: Contrasting Theory with Data. Science (Washington D C) 2009, 323(5915):732-737.

10. Rögl F: Palaeogeographic considerations for Mediterranean and Paratethys seaways (Oligocene to Miocene). Annalen des Naturhistorischen Museums in Wien 1998, 99:279-310.
11. O'dea A, Jackson JBC, Fortunato H, Smith JT, D'Croz L, Johnson KG, Todd JA: Environmental change preceded Caribbean extinction by 2 million years. Proc Natl Acad Sci USA 2007, 104(13):5501-5506.

12. Alva-Campbell Y, Floeter SR, Robertson DR, Bellwood DR, Bernardi G: Molecular phylogenetics and evolution of Holacanthus angelfishes (Pomacanthidae). Mol Phylogenet Evol 2010, 56(1):456-461.

13. Knowlton N, Weigt LA: New dates and new rates for divergence across the Isthmus of Panama. P Roy Soc Lond B Bio 1998, 265(1412):2257-2263.

14. Lessios HA: The Great American Schism: Divergence of Marine Organisms After the Rise of the Central American Isthmus. Annu Rev Ecol Evol Syst 2008, 39:63-91.

15. Klaus JS, Lutz BP, McNeill DF, Budd AF, Johnson KG, Ishman SE: Rise and fall of Pliocene free-living corals in the Caribbean. Geology 2011, 39(4):375-378.

16. Collins LS, Budd AF, Coates AG: Earliest evolution associated with closure of the Tropical American Seaway. Proc Natl Acad Sci USA 1996, 93(12):6069-6072.

17. Jackson JBC: The future of the oceans past. Philos T R SOC B 2010 365(1558):3765-3778.

18. O'dea A, Jackson J: Environmental change drove macroevolution in cupuladriid bryozoans. P Roy Soc B-Bio/ Sci 2009, 276(1673):3629-3634

19. Smith JT, Jackson JBC: Ecology of extreme faunal turnover of tropical American scallops. Paleobiology 2009, 35(1):77-93.

20. Todd JA, Jackson JBC, Johnson KG, Fortunato HM, Heitz A, Alvarez M, Jung $P$ : The ecology of extinction: molluscan feeding and faunal turnover in the Caribbean Neogene. P Roy Soc Lond B Bio 2002, 269(1491):571-577.

21. Budd AF, Johnson KG: Origination preceding extinction during late Cenozoic turnover of Caribbean reefs. Paleobiology 1999, 25(2):188-200.

22. Johnson KG: A phylogenetic test of accelerated turnover in Neogene Caribbean brain corals (Scleractinia: Faviidae). Palaeontology 1998, 41:1247-1268

23. Baird AH, Guest JR, Willis BL: Systematic and Biogeographical Patterns in the Reproductive Biology of Scleractinian Corals. Annu Rev Ecol Evol Syst 2009, 40:551-571.

24. Weil E, Vargas WL: Comparative aspects of sexual reproduction in the Caribbean coral genus Diploria (Scleractinia: Faviidae). Mar Biol 2010, 157(2):413-426.

25. Greenstein BJ, Curran HA, Pandolfi JM: Shifting ecological baselines and the demise of Acropora cervicornis in the western North Atlantic and Caribbean Province: A Pleistocene perspective. Coral Reefs 1998, 17(3):249-261

26. Mesolella KJ: Zonation of uplifted Pleistocene coral reefs on Barbados, West Indies. Science 1967, 156(3775):638-640.

27. Stanley SM: Paleoecology and diagenesis of Key Largo Limestone, Florida. Bull Amer Ass Petrol Geol 1966, 50(9):1927-1947.

28. Hunter IG, Jones B: Coral associations of the Pleistocene Ironshore Formation, Grand Cayman. Coral Reefs 1996, 15(4):249-267.

29. Johnson KG, Budd AF, Stemann TA: Extinction Selectivity and Ecology of Neogene Caribbean Reef Corals. Paleobiology 1995, 21(1):52-73.

30. Budd AF, Romano SL, Smith ND, Barbeitos MS: Rethinking the Phylogeny of Scleractinian Corals: A Review of Morphological and Molecular Data. Integr Comp Biol 2010, 50(3):411-427.

31. Kitahara MV, Cairns SD, Stolarski J, Blair D, Miller DJ: A Comprehensive Phylogenetic Analysis of the Scleractinia (Cnidaria, Anthozoa) Based on Mitochondrial CO1 Sequence Data. PLoS One 2010, 5(7):e11490.

32. Romano SL, Cairns SD: Molecular phylogenetic hypotheses for the evolution of scleractinian corals. Bull Mar Sci 2000, 67(3):1043-1068

33. Romano SL, Palumbi SR: Evolution of scleractinian corals inferred from molecular systematics. Science 1996, 271(5249):640-642.

34. Benzoni F, Stefani F, Stolarski J, Pichon M, Mitta G, Galli P: Debating phylogenetic relationships of the scleractinian Psammocora: molecular and morphological evidences. Contrib Zool 2007, 76(1):35-54.

35. Fukami H, Budd AF, Paulay G, Sole-Cava A, Chen CLA, Iwao K, Knowlton N: Conventional taxonomy obscures deep divergence between Pacific and Atlantic corals. Nature 2004, 427(6977):832-835.

36. Fukami H, Chen CA, Budd AF, Collins A, Wallace C, Chuang Y-Y, Chen C, Dai C-F, Iwao K, Sheppard C, et al: Mitochondrial and Nuclear Genes Suggest that Stony Corals Are Monophyletic but Most Families of Stony Corals Are Not (Order Scleractinia, Class Anthozoa, Phylum Cnidaria). PLoS One 2008, 3(9):e3222. 
37. Huang D, Licuanan WY, Baird AH, Fukami H: Cleaning up the 'Bigmessidae': Molecular phylogeny of scleractinian corals from Faviidae, Merulinidae, Pectiniidae and Trachyphylliidae. BMC Evol Biol 2011, 11:37.

38. Huang DW, Meier R, Todd PA, Chou LM: More evidence for pervasive paraphyly in scleractinian corals: Systematic study of Southeast Asian Faviidae (Cnidaria; Scleractinia) based on molecular and morphological data. Mol Phylogenet Evol 2009, 50(1):102-116.

39. Nunes F, Fukami H, Vollmer SV, Norris RD, Knowlton N: Re-evaluation of the systematics of the endemic corals of Brazil by molecular data. Coral Reefs 2008, 27(2):423-432.

40. Forsman ZH, Barshis DJ, Hunter $\mathrm{CL}$, Toonen RJ: Shape-shifting corals: Molecular markers show morphology is evolutionarily plastic in Porites. BMC Evol Biol 2009, 9

41. Rambaut A, Drummond AJ: Tracer v.1.5.; 2007. Available from http://beast. bio.ed.ac.uk/Tracer.

42. Veron JEN: Corals in space and time: the biogeography and evolution of the Scleractinia. Ithaca: Comstock/Cornell; 1995

43. Arnold ML: Natural hybridization and evolution. New York: Oxford University Press; 1997.

44. Johnson KG: Population-Dynamics of a Free-Living Coral - Recruitment, Growth and Survivorship of Manicina-Areolata (Linnaeus) on the Caribbean Coast of Panama. J Exp Mar Biol Ecol 1992, 164(2):171-191.

45. Hey J, Nielsen R: Integration within the Felsenstein equation for improved Markov chain Monte Carlo methods in population genetics. Proc Natl Acad Sci USA 2007, 104(8):2785-2790.

46. Rokas A, Williams BL, King N, Carroll SB: Genome-scale approaches to resolving incongruence in molecular phylogenies. Nature (London) 2003, 425(6960):798-804.

47. Rokas A, Carroll SB: More genes or more taxa? The relative contribution of gene number and taxon number to phylogenetic accuracy. Mol Biol Evol 2005, 22(5):1337-1344

48. McNeill DF, Eberli GP, Lidz BH, Swart PK, Kenter JAM: Chronostratigraphy of prograding carbonate platform margins: A record of sea-level changes and dynamic slope sedimentation, western Great Bahama Bank Subsurface Geology of a Prograding Carbonate Platform Margin, Great Bahama Bank: Results of the Bahamas Drilling Project: SEPM, Special Publication 2001, 70:101-136.

49. Jain S, Collins LS: Trends in Caribbean Paleoproductivity related to the Neogene closure of the Central American Seaway. Mar Micropaleontol 2007, 63(1-2):57-74.

50. Johnson KG: Synchronous planulation of Manicina areolata (Scleractinia) with lunar periodicity. Mar Ecol Prog Ser 1992, 87(3):265-273.

51. Szmant-Froelich A, Reutter M, Riggs L: Sexual Reproduction of FaviaFragum Lunar Patterns of Gametogenesis Embryogenesis and Planulation in Puerto-Rico. Bull Mar Sci 1985, 37(3):880-892.

52. Simpson C, Kiessling W, Mewis H, Baron-Szabo RC, Müller J: Evolutionary diversification of reef corals: a comparison of the molecular and fossil records. Evolution 2011, 65(11):3274-3284.

53. Yoder JB, Clancey E, Des Roches S, Eastman JM, Gentry L, Godsoe W, Hagey TJ, Jochimsen D, Oswald BP, Robertson J, et al: Ecological opportunity and the origin of adaptive radiations. J Evolution Biol 2010, 23(8):1581-1596.

54. Hughes TP, Baird AH, Bellwood DR, Card M, Connolly SR, Folke C, Grosberg $R$, Hoegh-Guldberg O, Jackson JBC, Kleypas J, et al: Climate change, human impacts, and the resilience of coral reefs. Science 2003, 301(5635):929-933.

55. Pandolfi JM, Bradbury RH, Sala E, Hughes TP, Bjorndal KA, Cooke RG, McArdle D, McClenachan L, Newman MJH, Paredes G, et al: Global trajectories of the long-term decline of coral reef ecosystems. Science 2003, 301(5635):955-958.

56. Van Oppen MJH, Gates RD: Conservation genetics and the resilience of reef-building corals. Mol Ecol 2006, 15(13):3863-3883.

57. Boekschoten GJ, Best MB: Fossil and Recent Shallow Water Corals from the Atlantic Islands Off Western Africa Cancap-Contribution No. 56. Zoologische Mededelingen (Leiden) 1988, 62(5-9):99-112.

58. Castro CB, Pires DO: Brazilian coral reefs: What we already know and what is still missing. Bull Mar Sci 2001, 69(2):357-371.

59. Carlon DB, Lippé C: Estimation of mating systems in Short and Tall ecomorphs of the coral Favia fragum. Mol Ecol 2011, 20(4):812-828.

60. Shearer TL, van Oppen MJH, Romano SL, Woerheide G: Slow mitochondrial DNA sequence evolution in the Anthozoa (Cnidaria). Mol Ecol 2002. 11(12):2475-2487.
61. Catmull J, Hayward DC, McIntyre NE, Reece-Hoyes JS, Mastro R, Callaerts P, Ball EE, Miller DJ: Pax-6 origins-Implications from the structure of two coral Pax genes. Dev Genes Evol 1998, 208(6):352-356.

62. Chiou C-Y, Chen IP, Chen C, Wu HJ-L, Wei NV, Wallace CC, Chen CA: Analysis of Acropora muricata calmodulin (CaM) indicates that scleractinian corals possess the ancestral Exon/Intron organization of the eumetazoan CaM gene. J Mol Evol 2008, 66(4):317-324.

63. Severance EG, Szmant AM, Karl SA: Single-copy gene markers isolated from the Caribbean coral, Montastraea annularis. Mol Ecol Notes 2004, 4(2):167-169.

64. Stephens M, Smith NJ, Donnelly P: A new statistical method for haplotype reconstruction from population data. Am J Hum Genet 2001, 68(4):978-989.

65. Stephens M, Scheet $P$ : Accounting for decay of linkage disequilibrium in haplotype inference and missing-data imputation. Am J Hum Genet 2005, 76(3):449-462

66. Flot JF: SEQPHASE: a web tool for interconverting phase input/output files and fasta sequence alignments. Mol Ecol Resour 2010, 10(1):162-166.

67. Katoh K, Misawa K, Kuma K, Miyata T: MAFFT: a novel method for rapid multiple sequence alignment based on fast Fourier transform. Nucleic Acids Res 2002, 30(14):3059-3066.

68. Katoh K, Toh H: Recent developments in the MAFFT multiple sequence alignment program. Brief Bioinform 2008, 9(4):286-298.

69. Maddison DR, Maddison WP: MacClade 4: Analysis of phylogeny and character evolution. Version 4.0. Sunderland: Sinauer Associates; 2000.

70. Guindon S, Gascuel O: A simple, fast, and accurate algorithm to estimate large phylogenies by maximum likelihood. Syst Biol 2003, 52(5):696-704.

71. Posada D: jModelTest: Phylogenetic model averaging. Mol Biol Evol 2008 , 25(7):1253-1256.

72. Huelsenbeck JP, Ronquist F: MRBAYES: Bayesian inference of phylogenetic trees. Bioinformatics 2001, 17(8):754-755

73. Ronquist F, Huelsenbeck JP: MrBayes 3: Bayesian phylogenetic inference under mixed models. Bioinformatics 2003, 19(12):1572-1574.

74. Stamatakis A: RAxML-VI-HPC: Maximum likelihood-based phylogenetic analyses with thousands of taxa and mixed models. Bioinformatics 2006, 22(21):2688-2690.

75. Stamatakis A, Hoover P, Rougemont J: A Rapid Bootstrap Algorithm for the RAxML Web Servers. Syst Biol 2008, 57(5):758-771.

76. Miller MA, Pfeiffer W, Schwartz T: Creating the CIPRES Science Gateway for Inference of Large Phylogenetic Trees. In Proceedings of the Gateway Computing Environments Workshop (GCE): 14 Nov. 2010; New Orleans, LA. 2010:1-8. http://www.ngbw.org/ee/index.php/portal/cite_us.

77. Drummond AJ, Rambaut A: BEAST: Bayesian evolutionary analysis by sampling trees. BMC Evol Biol 2007, 7:214.

78. Nylander JAA: MrModeltest v2:: Evolutionary Biology Centre, Uppsala University; 2004. http://www.abc.se/ nylander/mrmodeltest2/mrmodeltest2. html.

79. Ho SYW, Phillips MJ: Accounting for Calibration Uncertainty in Phylogenetic Estimation of Evolutionary Divergence Times. Syst Biol 2009, 58(3):367-380

80. Kumar S, Skjaeveland A, Orr RJS, Enger P, Ruden T, Mevik BH, Burki F, Botnen A, Shalchian-Tabrizi K: AIR: A batch-oriented web program package for construction of supermatrices ready for phylogenomic analyses. BMC Bioinforma 2009, 10.

doi:10.1186/1471-2148-12-123

Cite this article as: Schwartz et al:: Molecules and fossils reveal punctuated diversification in Caribbean "faviid" corals. BMC Evolutionary Biology 2012 12:123. 